\title{
GEM-QUALITY GROSSULAR GARNETS
}

\author{
By D. Vincent Manson and Carol M. Stockton
}

The gemological classification and identification of gem grossular garnets is examined through the study of $105 \mathrm{gem}$ quality grossulars. These specimens were measured for refractive index, specific gravity, absorption spectrum, color, and chemical composition. From these data, the authors were able to reexamine the ranges of physical and optical properties that are characteristic of the gem species grossular. In addition, they discuss the problems encountered in defining the two gem varieties of grossular, tsavorite and hessonite.

\section{ABOUT THE AUTHORS}

Dr. Manson is director of research and Ms. Stockton is senior research gemologist at the Gemological institute of America, Santa Monica, CA.

Acknowledgments: The authors wish to thank those employees of GIA who assisted in gathering data for this article. Thanks also go to Tino Hammid for the photograph in figure 1, to Mike Havstad for the photograph in figure 6 , and to Susan Kingsbury for the line drawings. Special thanks go to Arthur Chodos, of the California Institute of Technology, for the use of the microprobe and for his valuable advice and assistance with the chemical analyses.

01983 Gemological Institute of America rossular garnet occurs in a diversity of colors, inI cluding tones of orange, yellow, and green. Until recently, this garnet species encountered little popularity as a gemstone, and then only in its brownish orange variety hessonite. About 10 years ago, however, a large deposit of vivid green grossular was discovered in east Africa (Bridges, 1974). Popularization of this material followed the coining of the trade name "tsavorite" (now accepted as a variety by mineralogists), and grossular emerged as a significant gem species. More recently, another new east African garnet, tagged with the trade name "malaya" and easily confused with hessonite, has brought new attention to bear on grossular (Stockton and Manson, 19821.

Hessonite and tsavorite illustrate the inconsistency that surrounds the definition of many gem varieties. Hessonite is the name traditionally applied to the yellow, orange, or brown transparent variety of grossular. However, color descriptions of hessonite are varied and vague: "cinnamon-colored" and "yellow" (Dana, 1911), "yellowish and brownish red" (Deer et al. 1963), "brownish-yellow, through a brownish-orange to aurora-red" (Webster, 1975), "orange-brown" (Anderson, 1959), "light yellow to dark yellow shades" (Arbuniés-Andreu, 1975), "yellow-brown to orangy-brown" (Shipley, 1974), "orangy-yellow to orangy-brown" (Liddicoat, 1981). In addition to the lack of agreement we encountered on the precise range of hues associated with this variety, nowhere could we find mention of the saturation of color to which these various hues referred.

The original description of tsavorite as being similar in color to emerald (Bridges, 1974) is also rather vague. At what point does green grossular have sufficient depth and intensity of color to be considered tsavorite? This is much the same as the familiar question, At what stage does green beryl become emerald? The net result of this lack 


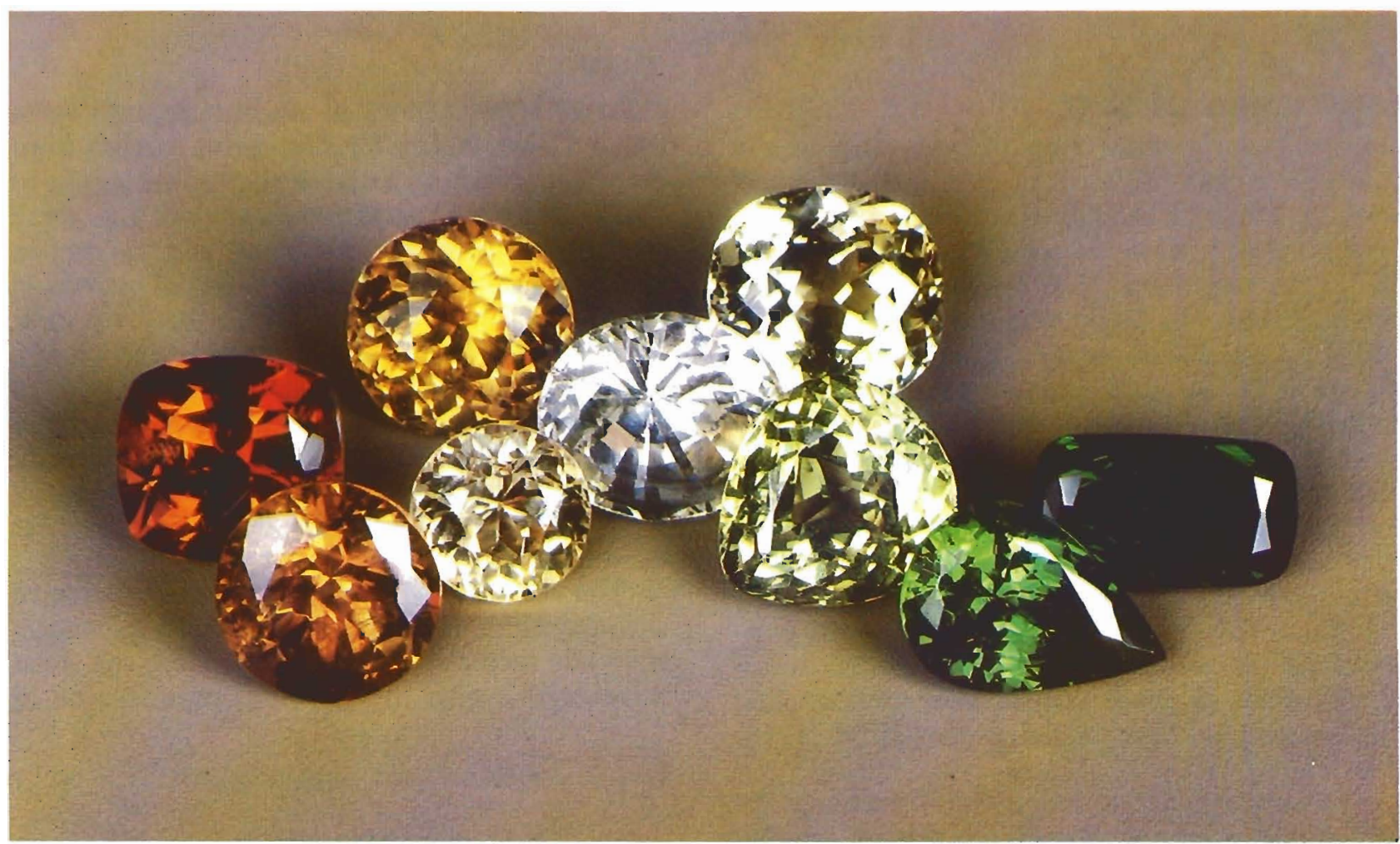

Figure 1. This selection of stones used in the grossular portion of the garnet study illustrates the range of colors examined.

of agreement with regard to the colors of the gem varieties of grossular is confusion among gemologists, understandably, as to the correct applications of these varietal terms.

The final goal of our study and review of garnets (Manson and Stockton, 1981; Stockton and Manson, 1982) is to provide clear, functional definitions of all the gem species and gem varieties of the garnet group. The size of this problem required that we divide the subject into a series of descriptive papers to be followed by a concluding article that proposes a cohesive gemological classification of the garnets on the basis of the data gathered. This study of the transparent grossular garnets continues the garnet project. Inasmuch as grossular has been well documented both mineralogically and gemologically, this portion of our study serves primarily to confirm previous work on the grossulars and to supply data /such as color description) not provided in earlier reports.

\section{DATA COLLECTION}

Stones were selected for study on the basis of gem quality, transparency, and colors that are typically associated with grossular. Chemical analyses from a previous study (Stockton and Manson,
1982) confirmed the identity of stones that might visually be mistaken for some other type of garnet. The resulting collection contained 105 specimens ranging from colorless through pale to intense hues of yellow, green, and orange (figure 1). Although orange grossulars were examined as part of the paper just cited, we included them here as well in order to compare all colors of grossular. Not included in this study are the massive, translucent materials (including pink and green) that in many cases actually belong to the separate species hydrogrossular (Deer et al., 1963). There have been cases of translucent grossular reported (Bank, 1980|, but this material is ornamental rather than gem quality.

Refractive index, specific gravity, spectrum, color, and chemical composition were determined for the 105 garnets selected. The instruments and methods used to obtain these data were described fully in a previous article in this journal (Manson and Stockton, 1981). The data gathered on the 105 gem garnets used in this study will be published at a later date, upon completion of the entire GIA garnet project, and are summarized below. Specific data will be provided on request to the authors. 


\section{DISCUSSION OF DATA}

Physical and Optical Data. Comparison of the ranges we obtained for refractive index and specific gravity with the values quoted by three other gemological references (table 1) reveals that the ranges we found in our 105 samples are somewhat broader than one might presume on the basis of the gemological literature. A graph of the relationship between refractive index and specific gravity among our 105 specimens (figure 2) suggests that, of the nongrossular components present, andradite appears to have the strongest effect on the departure of these properties from the values for pure grossular: 1.731 (McConnell, 1964) and 3.594 (Skinner, 1956), respectively. However, the scattering of points to either side of the grossular-andradite trend suggests that other influences, such as other end-member components, are present, as one might expect (Ford, 1915; Fleischer, 1937).

Comparison of our data with references in the mineralogy literature sometimes reveals discrepancies that result from the particular nature of our samples. Gem specimens are relatively inclusion-free, transparent, single crystals, while mineralogical specimens are frequently fractured and included such that they are not transparent even as single crystals. For example, data cited by Ford (1915) resulted in a low estimate of the specific gravity of pure grossular (3.530 rather than the 3.594 found by Skinner in 1956). It is recognized now that, as stated by Deer et al. (1963, p. 81), "garnets commonly have small inclusions of quartz or other minerals which cause the composite grain to have a low specific gravity." In fact, their data reflect this bias when compared with our results.

Absorption Spectra. We observed two basic shapes of spectral curves for grossular garnets on the recording spectrophotometer. Green stones exhib-

TABLE 1. Refractive index and specific gravity ranges for grossular garnets.

\begin{tabular}{lcc}
\hline Reference & Refractive index & Specific gravity \\
\hline Shipley (1974) & $1.74-1.75$ & $3.57-3.73$ \\
Webster (1975) & $1.742-1.748$ & approx. 3.65 \\
Liddicoat (1981) & approx. 1.735 & approx. 3.61 \\
Manson and & $1.731-1.754$ & $3.57-3.67$ \\
\multicolumn{2}{l}{ Stockton (present study) } & \\
\hline
\end{tabular}

ited two broad regions of absorption and two of transmission (figure 3). Absorption occurs from the short wavelength end of the visible region to about $460 \mathrm{~nm}$ and again in a broad region centered around approximately $603.5 \mathrm{~nm}$ and varying in width. However, these broad bands or regions of absorption can be discerned with the hand spectroscope only rarely, in some dark green stones. Transmission is centered around 525 to $550 \mathrm{~nm}$ in the green region, as might be expected, and in the far red around 700 to $735 \mathrm{~nm}$. This is virtually identical to the spectra observed by Gübelin and Weibel (1975) and by Amthauer (1975) for similar grossulars.

The second type of spectral curve, associated with colorless, yellow, and orange stones, shows gradually increasing transmission from the short wavelength region to maximum transmission in

Figure 2. Refractive index plotted against specific gravity for the 105 grossulars studied. The coordinate point for the ideal end member grossular is also shown $(X)$.

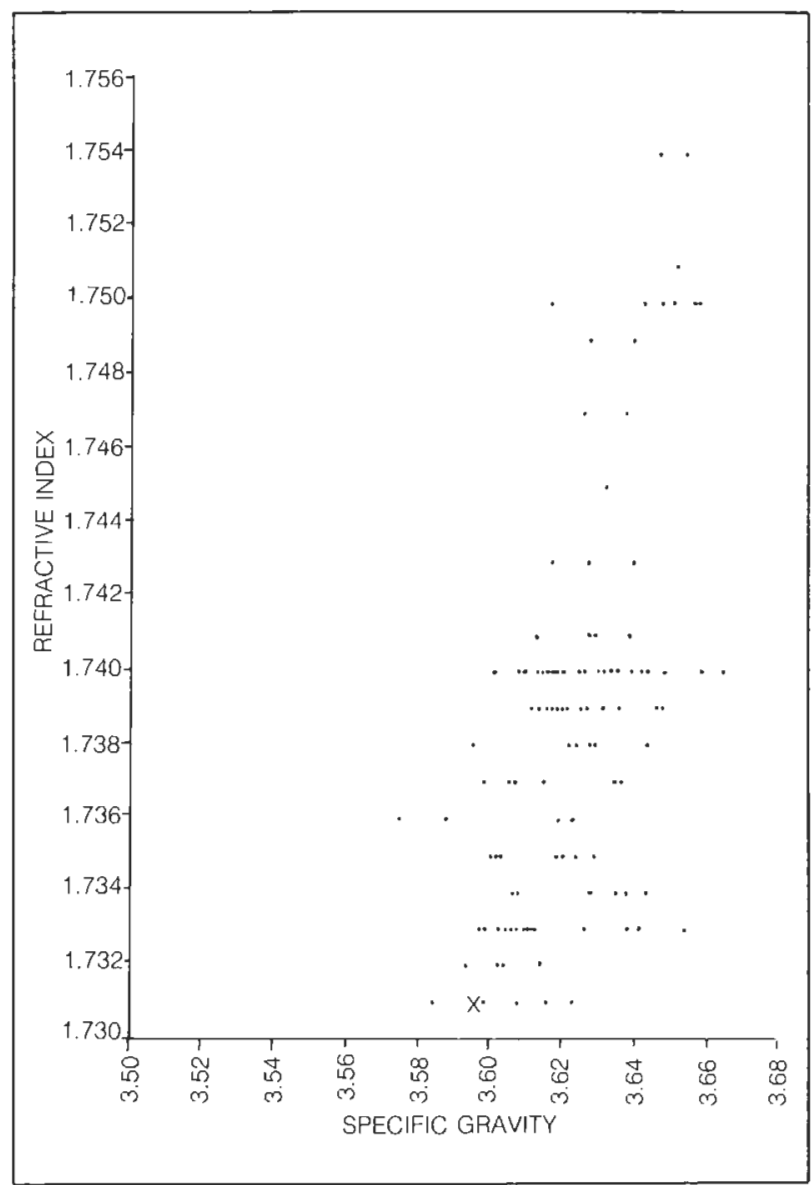




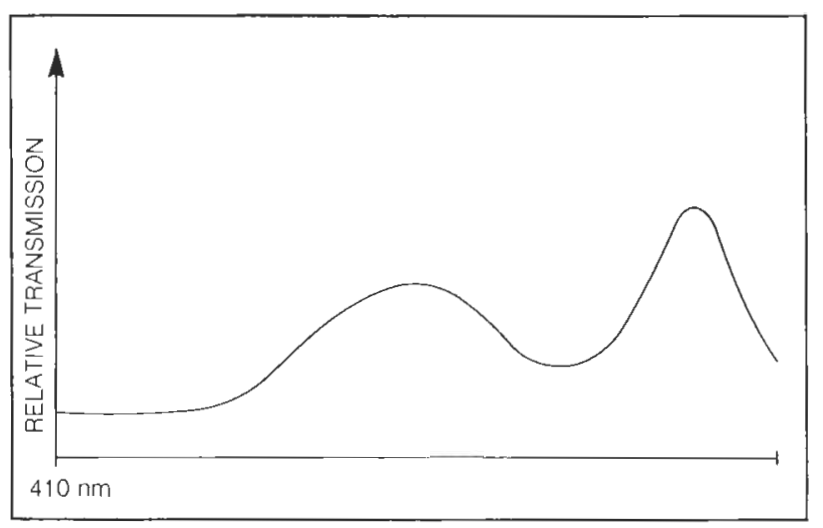

Figure 3. Representative spectral curve of a green grossular as observed with the spectrophotometer.

the yellow-to-orange region, depending on the color of the stone, followed by a rapid decrease in transmission to the end of the long wavelength region of the visible spectrum (figure 4). Most of the stones examined showed no sharp absorption bands, but a few showed a faint band around 434 $\mathrm{nm}$ that is probably due to $\mathrm{Fe}^{3+}$ (Amthauer, 1975; Slack and Chrenko, 1971). One light orange stone also had very faint bands at 418.5, 489.5, 503.5, and $529.5 \mathrm{~nm}$ that to our knowle'dge have not been observed elsewhere in grossular. This stone, however, is the most heavily included one in our collection, and these absorption bands may be related to the inclusions that pervade the specimen. In any case, none of these bands is strong enough to be seen with the hand spectroscope, so they are purely of academic interest to most jewelergemologists.

Chemistry. It has long been considered that grossular is chemically continuous with andradite and uvarovite and forms a subgroup with them (Winchell and Winchell, 1951). While the amount of andradite in the 105 gems we analyzed ranged from approximately 0 to $19 \%$, the most uvarovite we encountered was $1.5 \%$. In fact, no single endmember component other than andradite exceeded $7 \%$ in any of the gem grossulars we analyzed (table 2). The relative quantities of grossular and andradite compared to all the remaining components can be observed in the ternary diagram of these three divisions (figure 5).

Although examples of stones containing less than $75 \%$ and more than $20 \%$ grossular have been cited (e.g., Deer et al., 1963), we personally have observed no gem-quality stones in that range. Grossular appears to be chemically less inclined to mix with other end-member components to

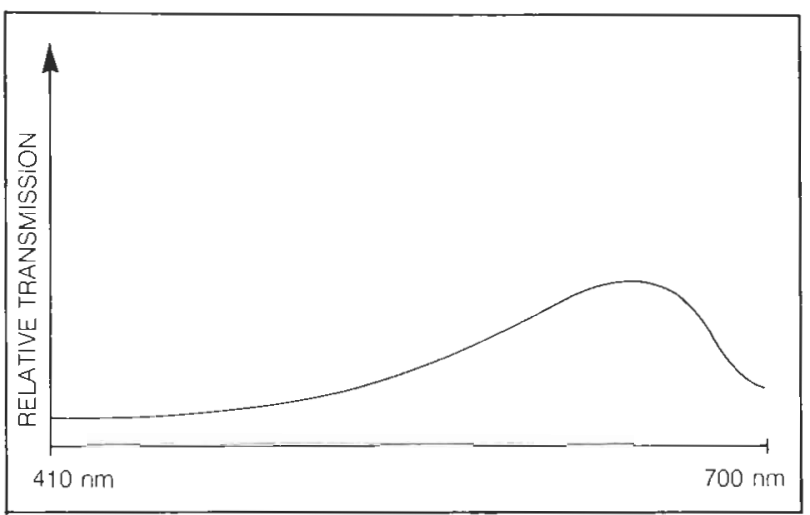

Figure 4. Representative spectral curve of a yellow-orange grossular as observed with the spectrophotometer.

produce large single crystals of gem quality, so grossulars of gem quality are generally very high in grossular content. The net result is that, chemically, grossular is easy to isolate and identify as a gem species.

Color and Chemistry. CIE color coordinates for the 105 grossulars were derived from ColorMaster notations (Manson and Stockton, 1981) and plotted in a chromaticity diagram (figure 6). The stones themselves were then placed on their respective coordinate points and photographed to show the complete range of colors for these gem grossulars (figure 7). This also illustrates, coincidentally, the quality of color description we have been able to obtain using the ColorMaster.

Pure grossular is colorless. Departing from this pure (and rarely seen) grossular are two distinct color trends that are evident on the chromaticity diagram (again, see figure 6). One of these proceeds through yellow-green to a pure, vivid green at one extreme, and the other proceeds through

TABLE 2. Weight percentage ranges of garnet end members calculated for the 105 grossulars studied.

\begin{tabular}{|c|c|c|}
\hline Formula & End member & Weight $\%$ \\
\hline $\mathrm{Ca}_{3} \mathrm{Ti}_{2}^{4+}\left(\mathrm{Fe}^{3+}, \mathrm{Si}\right)_{3} \mathrm{O}_{12}$ & Schorlomite & $0.02-2.14$ \\
\hline $\mathrm{Ca}_{3} \mathrm{Fe}_{2} \mathrm{Si}_{3} \mathrm{O}_{12}$ & Andradite & $0 \quad-19.07$ \\
\hline $\mathrm{Mn}_{3} \mathrm{~V}_{2} \mathrm{Si}_{3} \mathrm{O}_{12}$ & & -3.05 \\
\hline $\mathrm{Ca}_{3} \mathrm{~V}_{2} \mathrm{Si}_{3} \mathrm{O}_{12}$ & Goldmanite & -6.91 \\
\hline $\mathrm{Ca}_{3} \mathrm{Cr}_{2} \mathrm{Si}_{3} \mathrm{O}_{12}$ & Uvarovite & -1.51 \\
\hline $\mathrm{Mg}_{3} \mathrm{Cr}_{2} \mathrm{Si}_{3} \mathrm{O}_{12}$ & Knorringite & 0 \\
\hline $\mathrm{Mg}_{3} \mathrm{Al}_{2} \mathrm{Si}_{3} \mathrm{O}_{12}$ & Pyrope & -2.19 \\
\hline $\mathrm{Mn}_{3} \mathrm{Al}_{2} \mathrm{Si}_{3} \mathrm{O}_{12}$ & Spessartine & $0-3.15$ \\
\hline $\mathrm{Ca}_{3} \mathrm{Al}_{2} \mathrm{Si}_{3} \mathrm{O}_{12}$ & Grossular & $77.71-97.91$ \\
\hline $\mathrm{Fe}_{3} \mathrm{Al}_{2} \mathrm{Si}_{3} \mathrm{O}_{12}$ & Almandine & $0-3.35$ \\
\hline
\end{tabular}


Figure 5. Points for the 105 grossulars plotted on a ternary diagram that displays the relationship between grossular, andradite, and the sum of the remaining endmember components. Grossular is clearly the dominant component among these garnets.

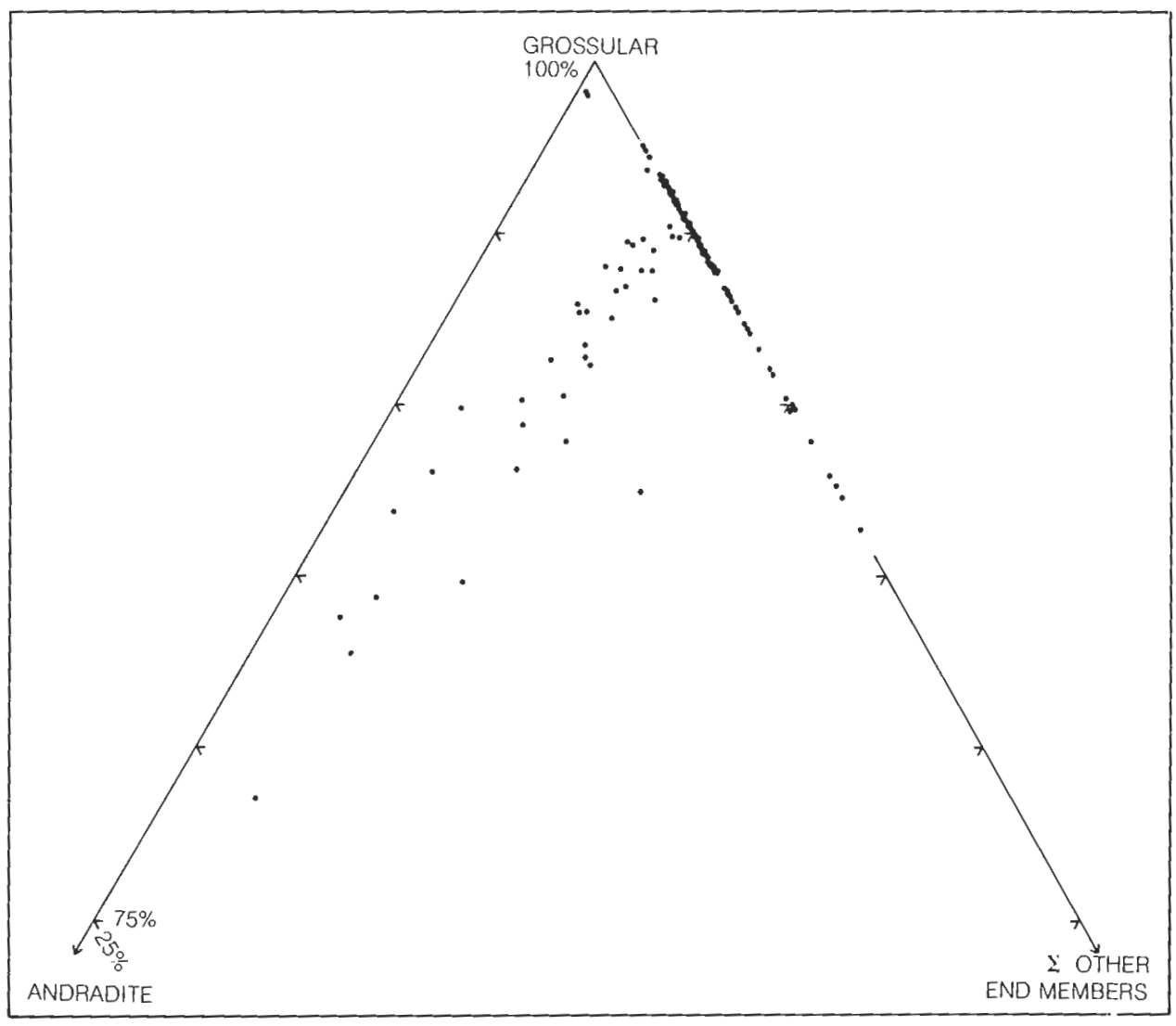

Figure 6. The CIE chromaticity diagram with an indication of the region reproduced in figure 7. X indicates the coordinates for colorless or neutral grey.

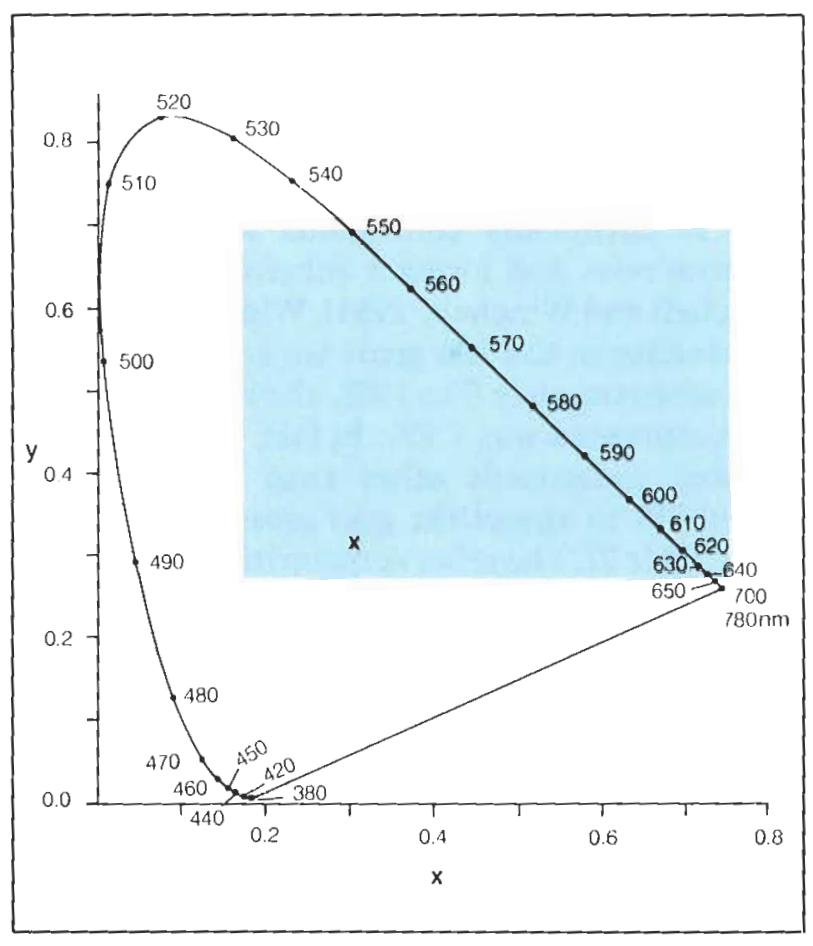




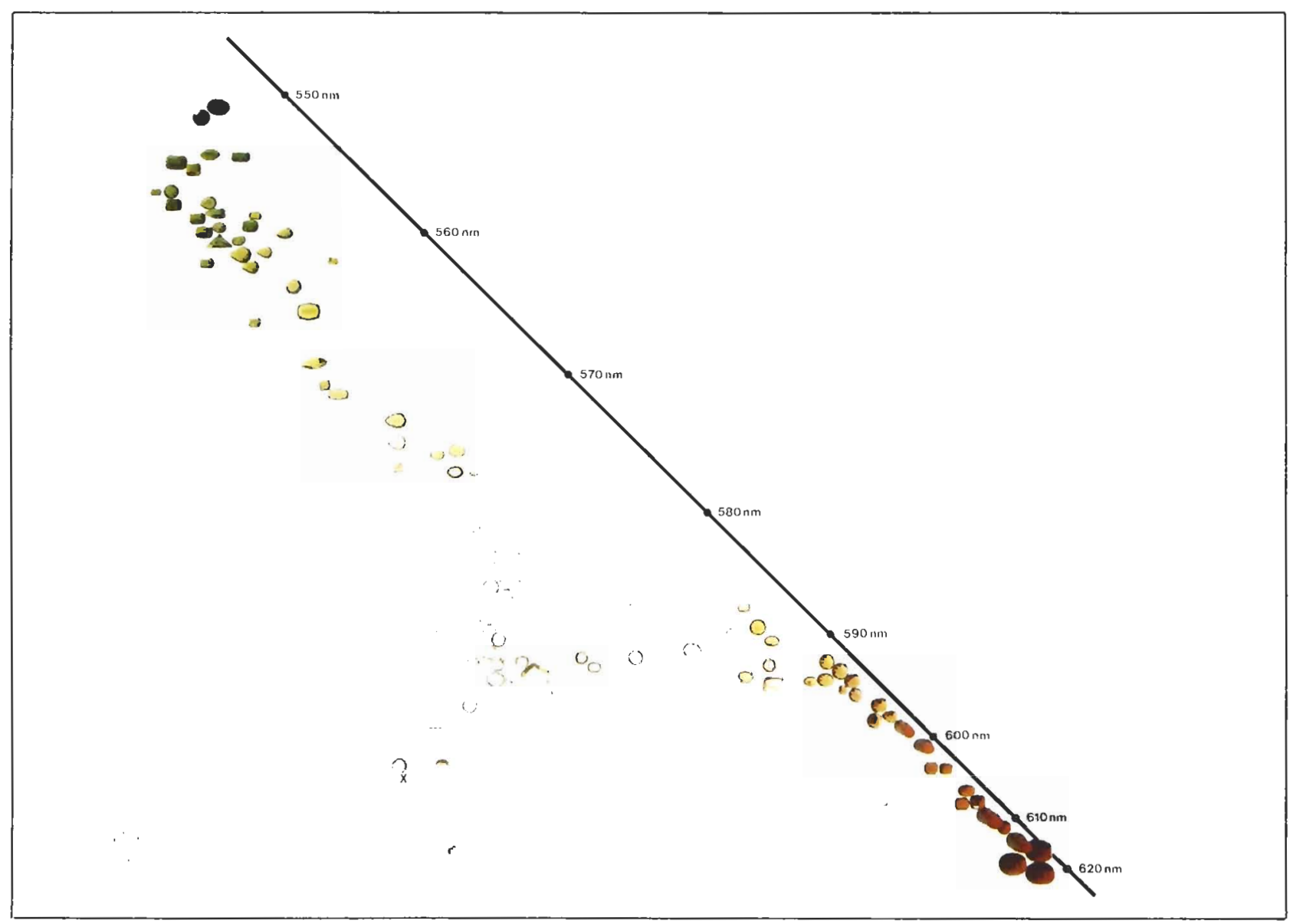

Figure 7. The green-through-orange region of the CIE chromaticity diagram with the 105 garnets positioned according to their $x$-y coordinates.

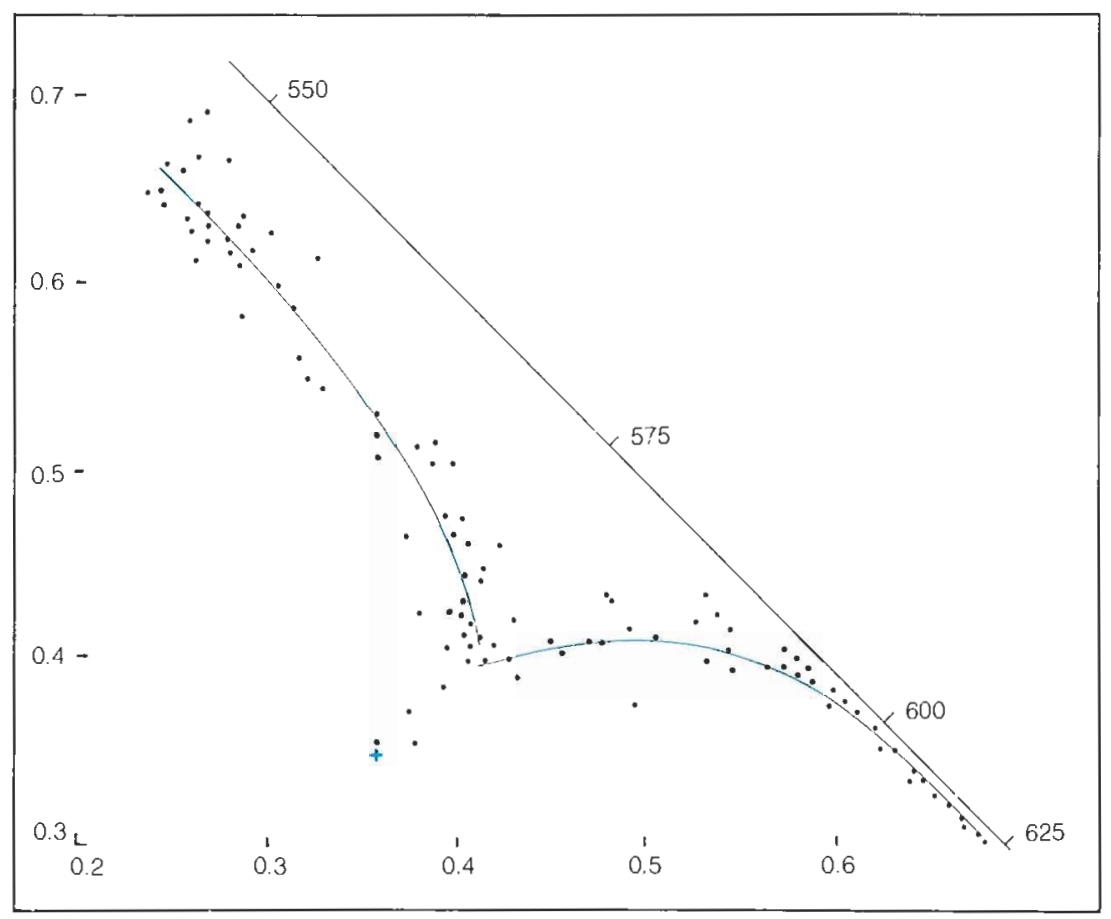

Figure 8. The green-through-orange region of the CIE chromaticity diagram with the color trend lines used to approximate changes in color of the 105 grossulars. 
andradite. Factors 2 and 3 become especially significant when we compare the oxides that they represent with the two color trends in grossulars.

Specifically, the measure of color change described above can be plotted against the quantities of the color-related oxides as identified by our factor analysis. Figure 9 shows that there is a direct relationship between the amount of $\mathrm{V}_{2} \mathrm{O}_{3}$ in a stone and increasing green, but there is no correlation between $\mathrm{V}_{2} \mathrm{O}_{3}$ and yellow and orange grossulars. $\mathrm{Cr}_{2} \mathrm{O}_{3}$ (figure 10 ) behaves remarkably like $\mathrm{V}_{2} \mathrm{O}_{3}$, although in smaller quantities /only two stones with more than $30 \%$ green contained no chromium). This suggests that generally the $\mathrm{V}_{2} \mathrm{O}_{3}: \mathrm{Cr}_{2} \mathrm{O}_{3}$ ratio in green grossulars is considerably greater than $1: 1$ but that both vanadium and chromium are usually responsible for the green in grossular garnets. A similar relationship between $\mathrm{V}^{3+}$ and $\mathrm{Cr}^{3+}$ has been observed by Switzer (1974) and by Amthauer (1975). An exception to this relationship between vanadium, chromium, and green coloration apparently exists in grossulars that are colored principally or solely by $\mathrm{Cr}_{2} \mathrm{O}_{3}$ (Amthauer, 1976; Wight and Grice, 1982). We have not yet had the opportunity to examine any such material and so have no idea how the green of these stones compares to that of the gems in our study.

By examining how the quantities of $\mathrm{FeO}$ and $\mathrm{Fe}_{2} \mathrm{O}_{3}$ calculated by our end-member program behave with respect to changes in color, we can in-

TABLE 3. Factor analysis of the oxides present in the 105 garnets studied.

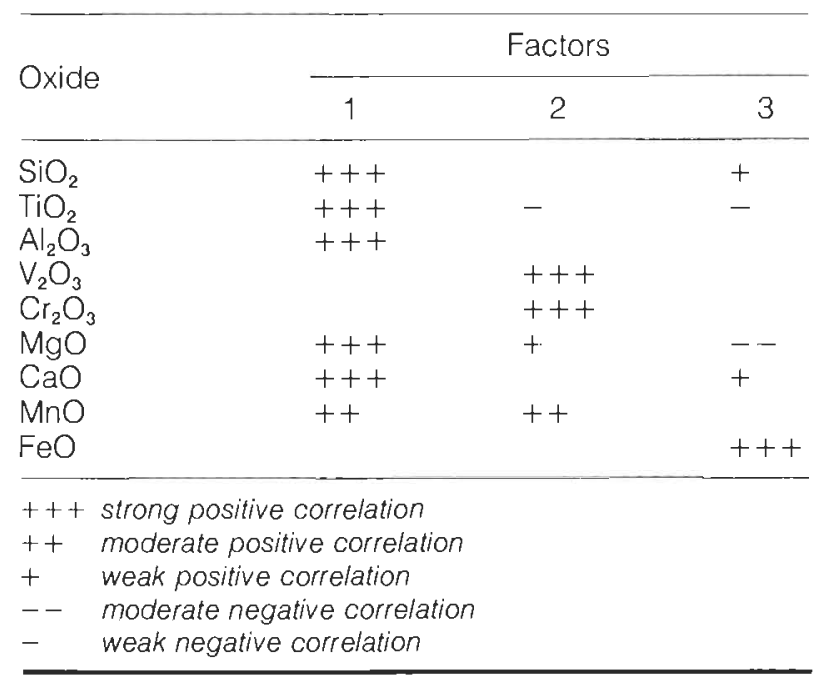

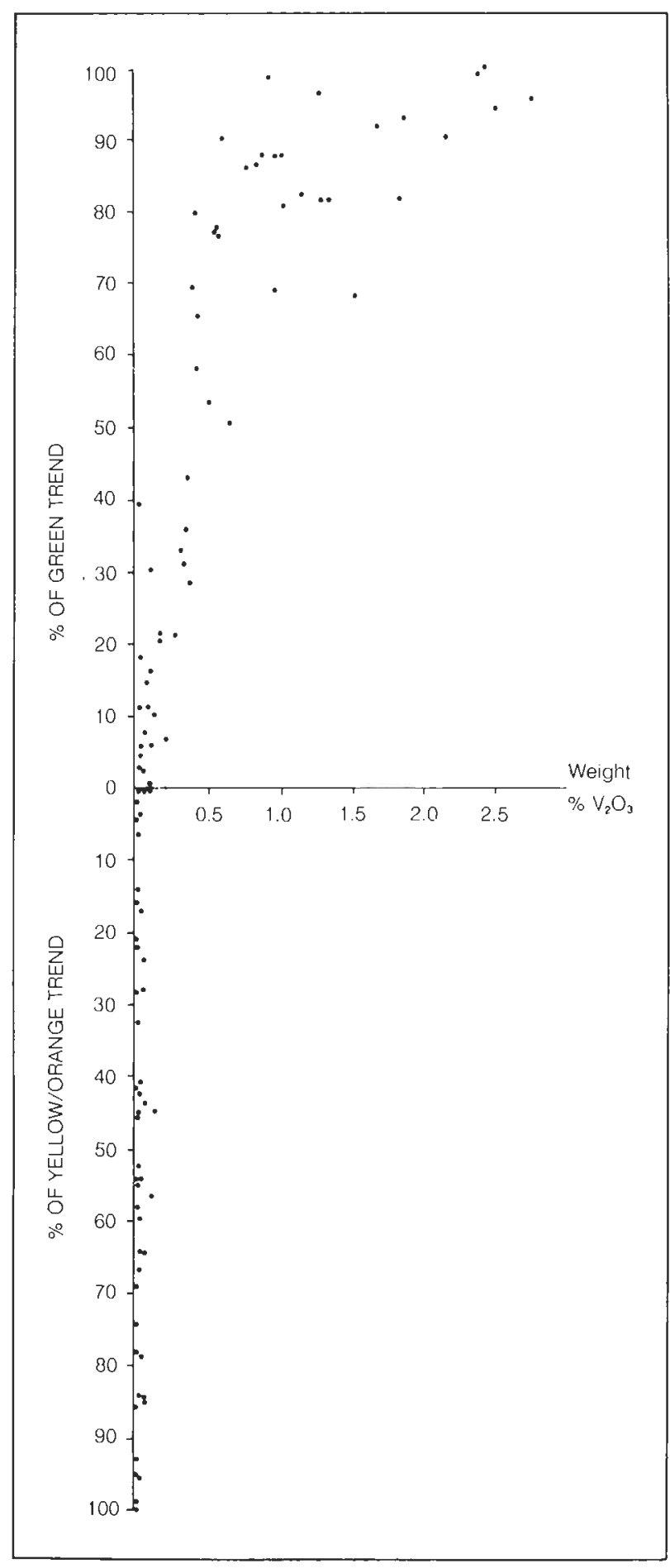

Figure 9. A comparison of the weight percentages of $\mathrm{V}_{2} \mathrm{O}_{3}$ in the 105 garnets with their respective positions along the color trend lines illustrated in figure $8 . \mathrm{V}_{2} \mathrm{O}_{3}$ shows a definite increase with respect to increasing green trend. 


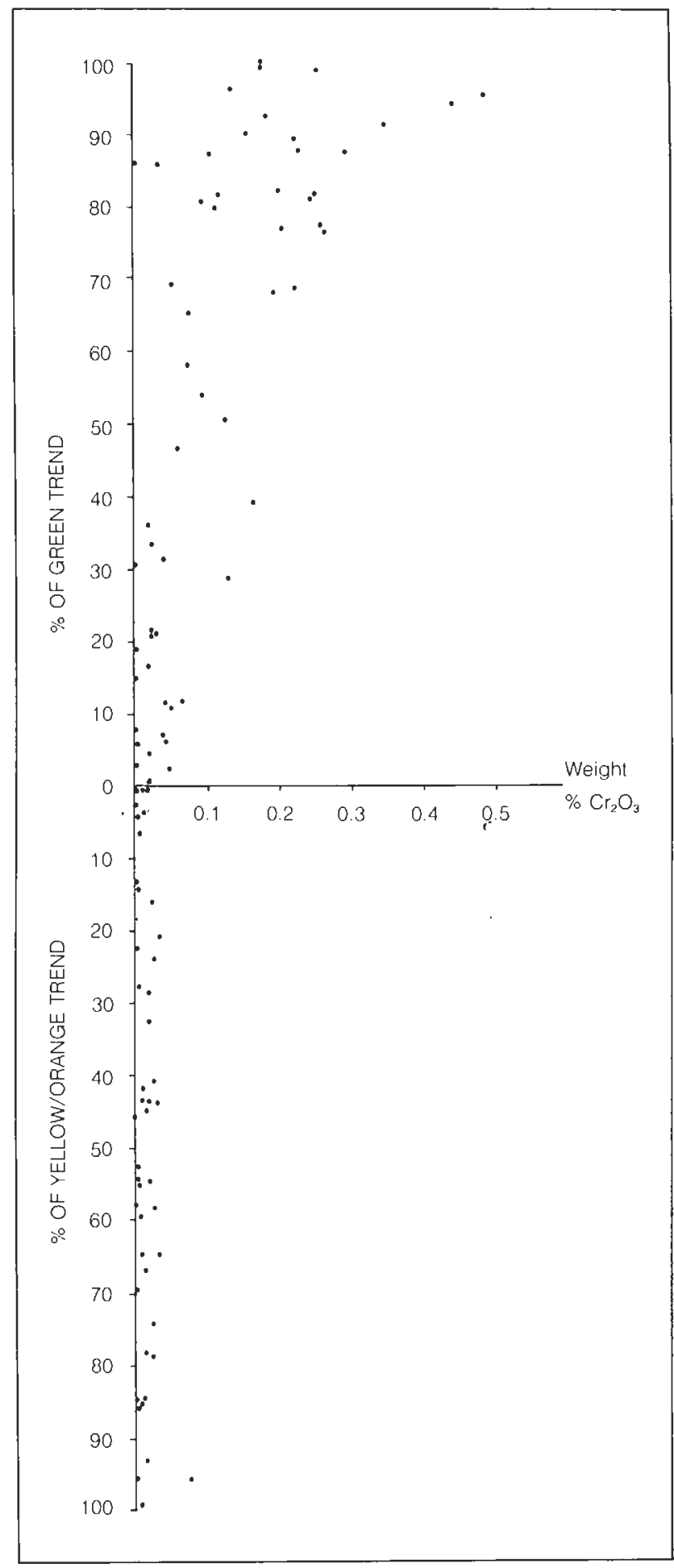

Figure 10. Weight percentage of $\mathrm{Cr}_{2} \mathrm{O}_{3}$ compared with changes along the color trend lines. $\mathrm{Cr}_{2} \mathrm{O}_{3}$ increases with the green trend here in much the same way as $V_{2} O_{3}$ does in figure 8. (Caution must be taken to consider the different scales along the $x$-axis in figures 9-12.) fer in which valence state $\left(\mathrm{Fe}^{2+} \text { or } \mathrm{Fe}^{3+}\right)^{*}$ iron is affecting color in grossulars. Figure 11 shows that the amount of $\mathrm{Fe}_{2} \mathrm{O}_{3}$ clearly increases with the change of color through yellow and orange to redorange and decreases as green increases. While $\mathrm{FeO}$ is conspicuously absent from the green grossulars (figure 12), its role in the color of yellow and orange grossulars remains ambiguous. In order to resolve this question, determination of the valence states of iron in yellow and orange grossulars by means more accurate than stoichiometric calculation is required. In fact, numerous such studies have been performed on the roles of $\mathrm{Fe}^{2+}$ and $\mathrm{Fe}^{3+}$ in grossular (e.g., Amthauer, 1975; Manning, 1972 and 1973). These have supported the relationship we found between yellow and orange grossular and $\mathrm{Fe}^{3+}$. A study by Manning and Tricker (1977) confirmed the role of $\mathrm{Fe}^{3+}$ in this context.

\section{CONCLUSIONS}

The gem species grossular presents few problems in description or identification. All of the gems we examined in this study contain more than $70 \%$ of the component $\mathrm{Ca}_{3} \mathrm{Al}_{2} \mathrm{Si}_{3} \mathrm{O}_{12}$, considerably more than the $50 \%$ required to assign them to a gem species. Mineralogical evidence based on nongem-quality material has shown that there is indeed a continuous chemical series between grossular, andradite, and uvarovite, but the grossulars examined in this study suggest that there is a gap in this series with regard to gem-quality grossular garnets. Until we receive evidence to the contrary, then, we can regard gem grossulars as discrete with respect to any other gem garnet species. Gem grossulars have been observed in this study to possess refractive indices from 1.731 to 1.754 and specific gravities of 3.57 to 3.67 . The hand spectroscope revealed no characteristic absorption bands for the 105 grossulars examined, in support of past observations.

Considering the effect that the application of varietal names has on the appreciation of gemstones, the precise definition of gem varieties is of some importance. The two gem varieties of grossular, hessonite and tsavorite, lack such def-

\footnotetext{
" $\mathrm{Fe}^{2+}$ is the valence state of iron in $\mathrm{FeO} ; \mathrm{Fe}^{3+}$ is the valence state of iron in $\mathrm{Fe}_{2} \mathrm{O}_{3}$.
} 


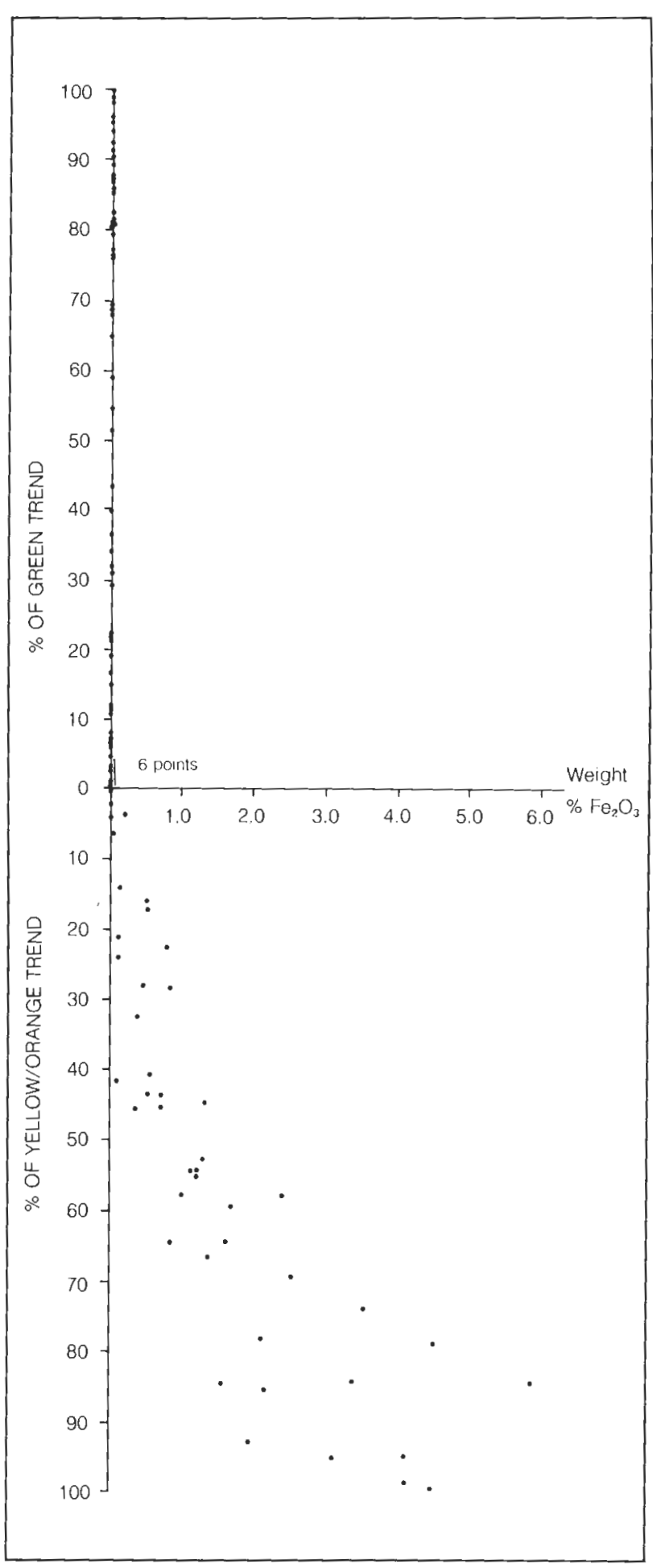

Figure 11. Weight percentage of $\mathrm{Fe}_{2} \mathrm{O}_{3}$ as determined by the end-member calculations compared to changes along the color trend lines for the 105 grossulars. $\mathrm{Fe}_{2} \mathrm{O}_{3}$ increases with the increase along the yellowlorange trend line.

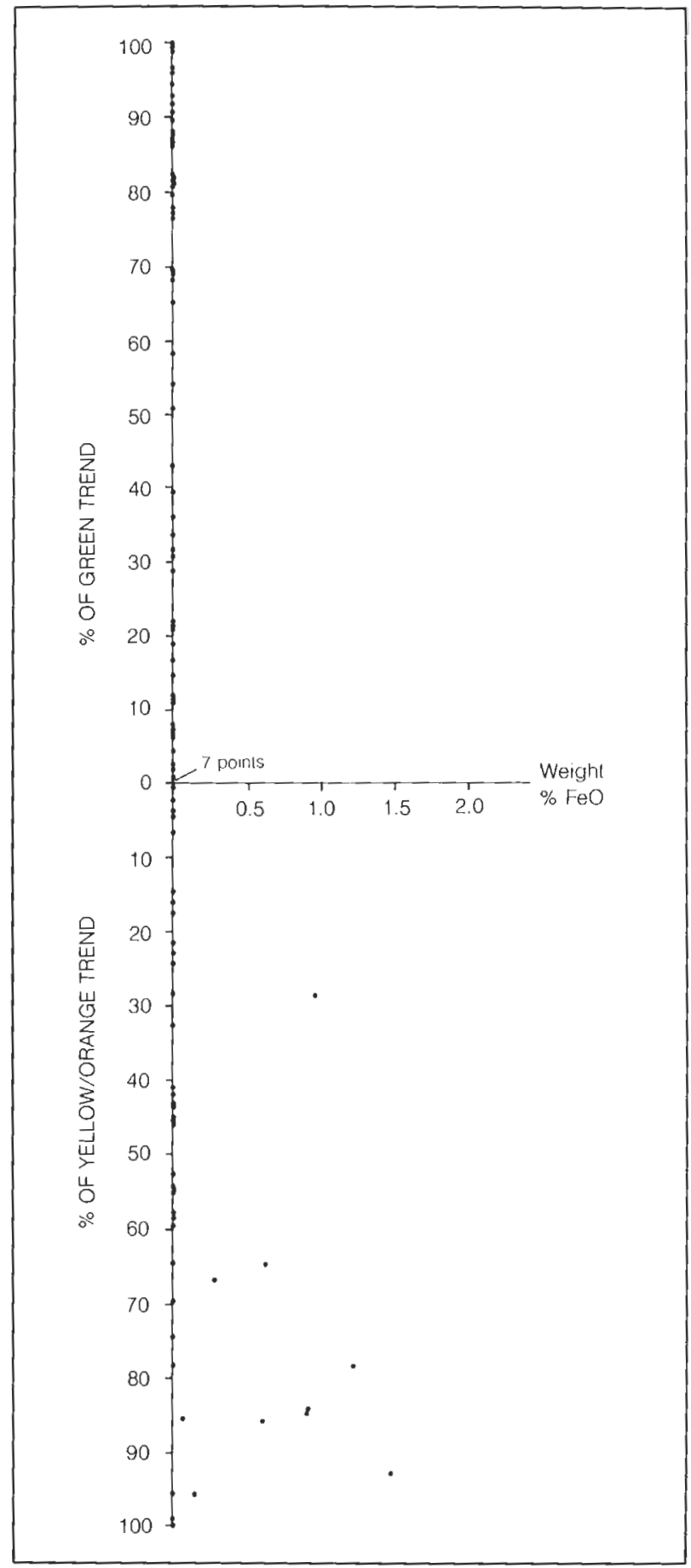

Figure 12. Weight percentage of $\mathrm{FeO}$ as determined by the end-member calculations compared with changes along the color trend lines. While FeO is present only in some stones located along the yellowlorange color trend line, no clear-cut correlation can be observed between changing yellowlorange color and the amount of FeO present. 
inition, as do most varieties in gemology. In the case of grossular, we have been able to observe a correlation between color and certain chemical elements that strongly supports the use of varietal distinctions. However, as with red and violet garnets, including rhodolite, the causes of color are not always so readily determined. Before we can define any varieties of garnets, therefore, we must review all the variables related to the varietal classification of gem garnets in order to formulate general rules that can be applied uniformly across the group. The concluding paper of the garnet project will include our recommendations for the precise definition of the gem varieties hessonite and tsavorite.

\section{REFERENCES}

Amthauer G. (1975) Zur Kristallchemie und Farbe grüner und brauner Grossulare aus Tansania. Zeitschrift der Deutschen Gemmologischen Gesellschaft, Vol. 24, No. 2, pp. 61-72.

Amthauer G. (1976) Kristallchemie und Farbe chromhaltiger Granate. Neues Jahrbuch für Mineralogie Abhundlangen, Vol. 126, No. 2, pp. 158-186.

Anderson B.W. (1959) Properties and classification of individual garnets. Journal of Gemmology, Vol. 7, No. 1, pp. 1-7.

Arbunies-Andreu M., Bosch-Figueroa J.M., Font-Altabá M, Traveria-Cros A. (1975) Physical and optical properties of garnets of gem quality. Fortschritte Mineralogie, Vol, 52, pp. $531-538$.

Bank H. (1980) Granate aus Mexiko. Zeitschrift der Deutschen Gemmologischen Gesellschaft, Vol. 29, Nos. 3 and 4, pp. 194-195.

Bridges C.R. (1974) Green grossularite garnets ("tsavorites") in East Africa. Gems \&) Gemology, Vol. 14, No. 10, pp. $290-295$

Dana E.S. (1911) Descriptive Mineralogy, 6th ed. John Wiley \& Sons, New York, p. 440.

Deer N.A., Howie R.A., Zussman J. (1963) Rock-Forming Minerals, Vol. 1, Ortho- and Ring Silicates. Longman Group Ltd., London, pp. 77-112.

Fleischer N.H. (1937) The relation between chemical com position and physical properties in the garnet group. American Mineralogist, Vol. 22, pp. 751-759.
Ford W.E. (1915) A study of the relations existing between the chemical, optical and other physical properties of the members of the garnet group. American /ournal of Science, 4 th series, Vol. 40, No. 235, pp. 33-49.

Gübelin E.J., Weibel M. (1975) Green vanadium grossular garnet from Lualenyi, near Voi, Kenya. Lapidary Joumal, Vol. 29, No. 2, pp. 402-426.

Liddicoat R.T. Jr. (1981) Handbook of Gern Identification. Gemological Institute of America, Santa Monica, CA, pp. 248-249.

Manning P.G. (1972) Optical absorption spectra of $\mathrm{Fe}^{3+}$ in octahedral and tetrahedral sites in natural garnets. Canadion Mineralogist, Vol. 11, pp. 826-839.

Manning P.G. (1973) Intensities and half-widths of octahedral$\mathrm{Fe}^{3+}$ crystal-field bands and Racah parameters as indicators of next-nearest-neighbor interactions in garnets. Canadian Mineralogist, Vol. 12, pp. 215-218.

Manning P.G., Tricker M.J. (1977) A Mössbauer spectral study of ferrous and ferric ion distributions in grossular crystals: evidence for local crystal disorder. Canadian Mineralogist, Vol. 15, pp. 81-86

Manson D.V., Stockton C.M. (1981) Gem garnets in the redto-violet color range. Gems \&) Gemology, Vol. 17, No. 4, pp. 191-204.

McConnell D. (1964) Refringence of garnets and hydrogarnets. Canadian Mineralogist, Vol. 8, pp. 11-12.

Shipley R.M. (1974) Dictionary of Gems and Gemology. Gemological Institute of America, Santa Monica, CA, p. 89.

Skinner B.J. \{1956) Physical properties of end-members of the garnet group. American Mineralogist, Vol. 41, pp. 428436.

Slack G.A., Chrenko R.M. (1971) Optical absorption of natural garnets from 1000 to 30,000 wavenumbers. Joumal of the Optical Society of America, Vol. 61, No. 10, pp. 13251329.

Stockton C.M., Manson D.V. (1982) Gem garnets: the orangeto red-orange color range. In International Gemological Symposium Proceedings 1982, Gemological Institute of America, Santa Monica, CA, pp. 327-338.

Switzer G.S. (1974) Composition of green garnet from Tanzania and Kenya. Gems ef Gemology, Vol. 14, No. 10, pp. $296-297$

Webster R. (1975) Gems, Shoe String Press, Hamden, CT, pp. 155-158.

Wight W., Grice J.D. (1982) Grossular garnet from the Jeffrey Mine, Asbestos, Quebec, Canada. Journal of Gemmology, Vol. 18, No. 2, pp. 126-130.

Winchell A.M., Winchell H. (1951) Elements of Optical Mineralogy, Part II, Descriptions of Minerals. John Wiley \& Sons, New York, pp. 483-489. 